\title{
Characteristics of Irregular Column Capitals in Ottoman Mosques with Courtyards
}

Nil Orbeyi*

\section{Abstract}

The aim of this article is to examine the construction techniques of the irregular column capitals which are located at the junction of portico and courtyard arcades (revak) of six Ottoman mosques. The porticos height of the closed-courtyard mosques built during the Ottoman period regarding is mostly equal. However, in six cases, the porticos of the mosques are higher than their side porticos, which led alternative solutions to keep the continuity of the arcade surrounding the courtyard. The first phase of this study focuses on the construction techniques and materials of the column capitals in Ottoman architecture and the second phase deals with irregular capitals including their characteristics (sizes, materials, and relations with other building elements). For this purpose, detailed drawings were prepared through the site examinations and the literature review. As a result, despite that their size and shape vary depending on construction period, the relationship between last prayer hall and courtyard, structural aspects, and visual concern, their construction techniques, materials, and components show similar properties.
Keywords: Column, capital, constructive details, design principles, portico, Ottoman architecture

*Assist. Prof. Dr. Vocational School of Architectural Restoration Programme, Mimar Sinan Fine Arts University, Istanbul, Turkey. ORCID

E-mail: nil.orbeyi@msgsu.edu.tr 


\section{INTRODUCTION}

In Ottoman mosques, portico supported by columns is attached to the primary structure (prayer hall) on the north side to provide additional space for the community in case the prayer hall was full or closed. Although the scale and plan layout of mosques varies throughout history, the portico has always been one of the most emphasized parts of the mosques (Kuran, 1964; Özüdoğru, 2005; Mülayim, 2008; Çuhadar, 2011). While it was a single place in the early period of Ottoman architecture (1299-1501), it was transformed into a closed courtyard with the addition of arcades in three directions, especially in the large-scale mosques in the Classical period (1501-1703) (Mülayim, 2008; Orbeyi, 2016). Although the porticos of these mosques are mostly of equal height (Figures 1a, 2a), the porticos of some mosques were designed to be higher than their side porticos (Figures $1 b, 2 b$ ).

Figure 1. a) The closed-courtyard of the İstanbul Şehzade (Şehzadebaşı) Mosque, b) The closed-courtyard of the Edirne Üç Şerefeli Mosque (Source: Author, 2018)

Figure 2. a) Section and plan of the İstanbul Şehzade Mosque (Redrawn from Ülgen, 1989), b) Section and plan of the Edirne Üç Şerefeli Mosque (Redrawn from Ayverdi, 1976)
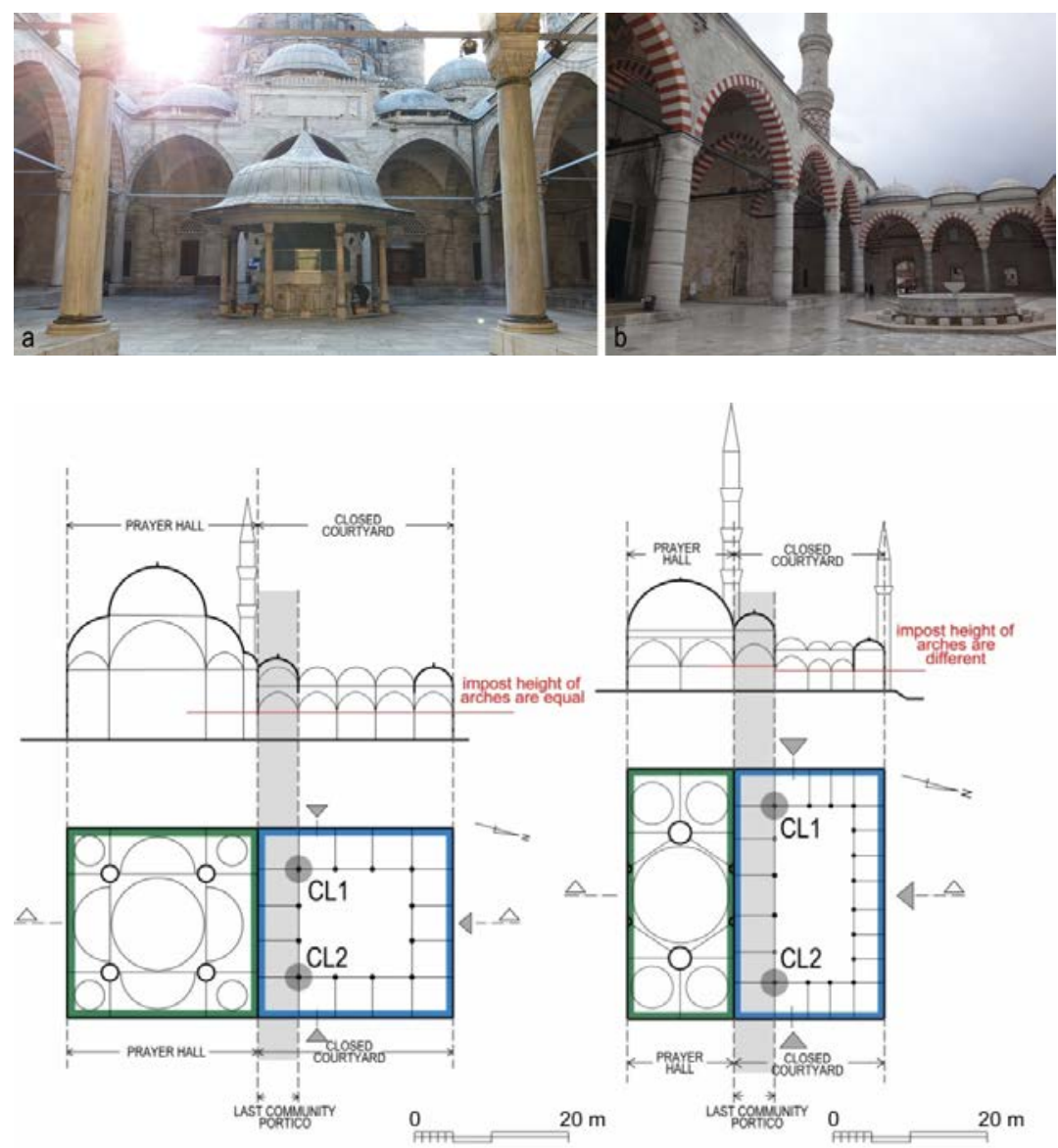

a)

b)

This formation is seen in six mosques that were built at different times over a period about 40

0 years (from the 15th to 18th centuries): Üç Şerefeli Mosque, Selimiye Mosque, Fatih Mosque, Süleymaniye Mosque, Kara Ahmed Pasha Mosque, and Yeni Valide Mosque. Except for the Üç 
Characteristics of Irregular Column Capitals in Ottoman Mosques with Courtyards

Şerefeli Mosque and Selimiye Mosque, all the structures which are investigated in this research were built in Istanbul (Figure 3).

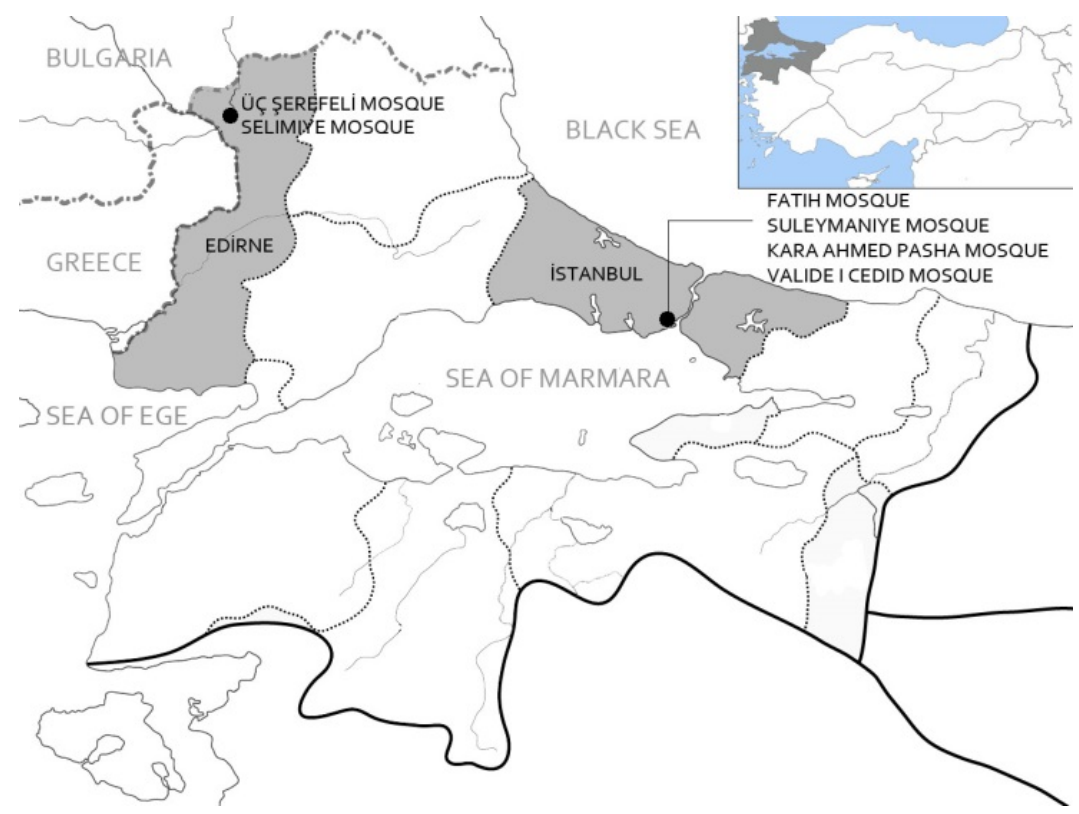

The height difference between the portico and arcades of the courtyard of these mosques caused the builders to use two capitals at different heights for the CL1 and CL2 columns, which are in structurally critical locations unlike the other columns (Figures $1 \mathrm{~b}, 2 \mathrm{~b}$ ). This altitude difference was probably preferred for several reasons:

- Emphasis on the entrance facade: Supporting monumentality by emphasizing the last community portico and strengthening the pyramidal effect (Kuran, 1964);

- Visual concern: Trying to give the impression that the portico was part of the prayer hall. For example according to Ayverdi (1976), in the Edirne's Üç Şerefeli Mosque, the portico was built upward from the side porticos to show the narrow prayer hall larger (Fig. 2b);

- Adherence to tradition: The desire to maintain the traditional layout of the Ottoman Early Period (for construction built during this period, see Ayverdi and Yüksel, 1976), especially in the earliest example of the case studies (Üç Şerefeli Mosque) of the closed courtyard type (Mülayim, 2008; Orbeyi, 2016);

- The influence of patronage: According to Necipoğlu (2005), the similarities in some mosques show that the patrons' requests about the details they like in different structures constituted an important factor affecting the design process $^{1}$. The height
Figure 3. İstanbul and Edirne in the map of Marmara Region (Redrawn form Google map)

1 For example, the using of double porticos in the mosques of Rustem Pasha, his wife Mihrimah Sultan, and his brother Sinan Pasha (Necipoğlu, 2005). 
differences in porticos may have been made depending on similar reasons.

Tanyeli (1999) state that the first comprehensive example of Ottoman architecture's attempt to make its technical knowledge in writing is the text in which Ahmed Efendi described the construction of the Nuruosmaniye Mosque in the mid-18th century (For the studies made after this date, see: Tanyeli, 2009). Although no written sources are describing directly the construction techniques of structures built before that date, we can obtain information about the names, sizes, and materials of building elements from archived documents (The Prime Ministry Ottoman Archives (BOA), account and construction books of the buildings (Barkan, 1979), etc.). In addition to historical documents, the examination of buildings that have preserved their original structure to the present day also provides information about the construction techniques and materials. Based on these documents, a limited number of studies have been conducted on the columns of the Ottoman architecture. These studies generally concern the columns under the category of building elements (Yorulmaz, 1986; Ahunbay, 1988; Alioğlu, 1991; Tayla, 2007; Uluengin, 2014) or are about the sizes, shapes, and material characteristics (Alper, 1998; Sönmezer, 2002; Mülayim, 2008; Orbeyi, 2012). In Orbeyi's study (2012), which deals with three of the six differently-shaped column's capitals (Süleymaniye, Selimiye, and Kara Ahmed Pasha Mosques), the capitals were examined only according from the decorative point of view.

\section{METHODOLOGY}

This study focuses on the closed-courtyard mosques that were built between the 16th and 18th centuries. In the first phase, the columns in Ottoman architecture were examined depending on their components, construction techniques, and materials. In the second phase, irregular capitals' parts were examined depending on their sizes, materials, and relationships with the other construction elements by using plan and section drawings. In this stage also the repairs of the structures were investigated. Interventions were related to columns and capitals in these repairs are presented in the text together with their accessible visuals. The construction technology and components of an ordinary column are known from archival documents (Barkan, 1979; Tanyeli \& Tanyeli, 1993, Ahunbay, 1988; Alioğlu, 1991; Tayla, 2007; Macaulay, 2010, Uluengin, 2014) and restoration reports of the structures (Aksu and Alaca, 2013, Ceylan, 2013). However, since there are no documents for irregular columns, 
documents concerning the possible construction technology and components of these columns were prepared depending, on the results obtained from ordinary column components and on-site examinations. In this context, structural surveys of the capitals were initially prepared. The survey drawings consist of two plans and two elevations. Plan 1, in which the lower and upper part of capitals can be seen together, allows comparison of the capitals. In Plan 2, only the upper part of capital and relationships with the lower arches of the cylindrical shaft can be seen. The last section of the paper describes the irregular columns' similarities, differences, and construction details, depending on the data obtained from this study. The mosques examined in this study, except Kara Ahmet Pasha Mosque, have recently been restored. Restoration of Kara Ahmet Pasha Mosque will also start soon. In the study, the current statuses of the buildings were examined.

\section{CONSTRUCTION TECHNIQUES AND MATERIALS OF THE COLUMN'S CAPITALS IN OTTOMAN ARCHITECTURE}

The column, which has been the most common vertical element in many civilizations, usually appears as a rounded shaft with a capital and a base. Although the forms of capitals vary according to civilization and period in use, its dimensions were related to the structural characteristic of the building such as the sizes of the arches connected to the capitals, the connecting directions of the arches to the columns, and the columns' locations in the structure.

In Ottoman architecture, there are two recognized types of capitals: (1) the stalactite or muqarnas and (2) the lozenge (baklavalı). In many constructions, they were concomitantly used. The columns consisted of three parts: (1) the capital; (2) the shaft; and (3) the base (Figure 4). The shaft was generally made of Egyptian and Kestanbolic granite, red porphyry, Marmara marble, and various colors of serpentine breccia monolithic stone blocks (Ahunbay, 1988; Goodwin, 2003; Kolay and Çelik, 2007, 2009; Mülayim, 2010; Ahunbay, 2012; Uluengin, 2014). The base, mostly made of marble or granite, was placed between the shaft and the ground and provided even transmission of the concentrated load by the column. The capitals were made mostly of marble. Capitals with muqarnas, which were made with intensive craftsmanship, can be seen in the main places (such as portico, prayer hall, etc.) of the mosques. For example, while two types of capitals had been used in the side porticos, the muqarnas schema was generally preferred for the portico (Kadırga Sokullu Mehmed Pasha Mosque, Rüstem Pasha Mosque, Kılıç Ali Pasha Mosque, Üsküdar Mihrimah Sultan Mosque, etc.) In the monumental mosques, the ground of the porticos is raised on a platform (sofa), and the 
column's bases are integrated with it. Thus, a more enduring connection has been established, which is useful especially in cases of earthquakes (Ahunbay, 1988) (Figure 4).

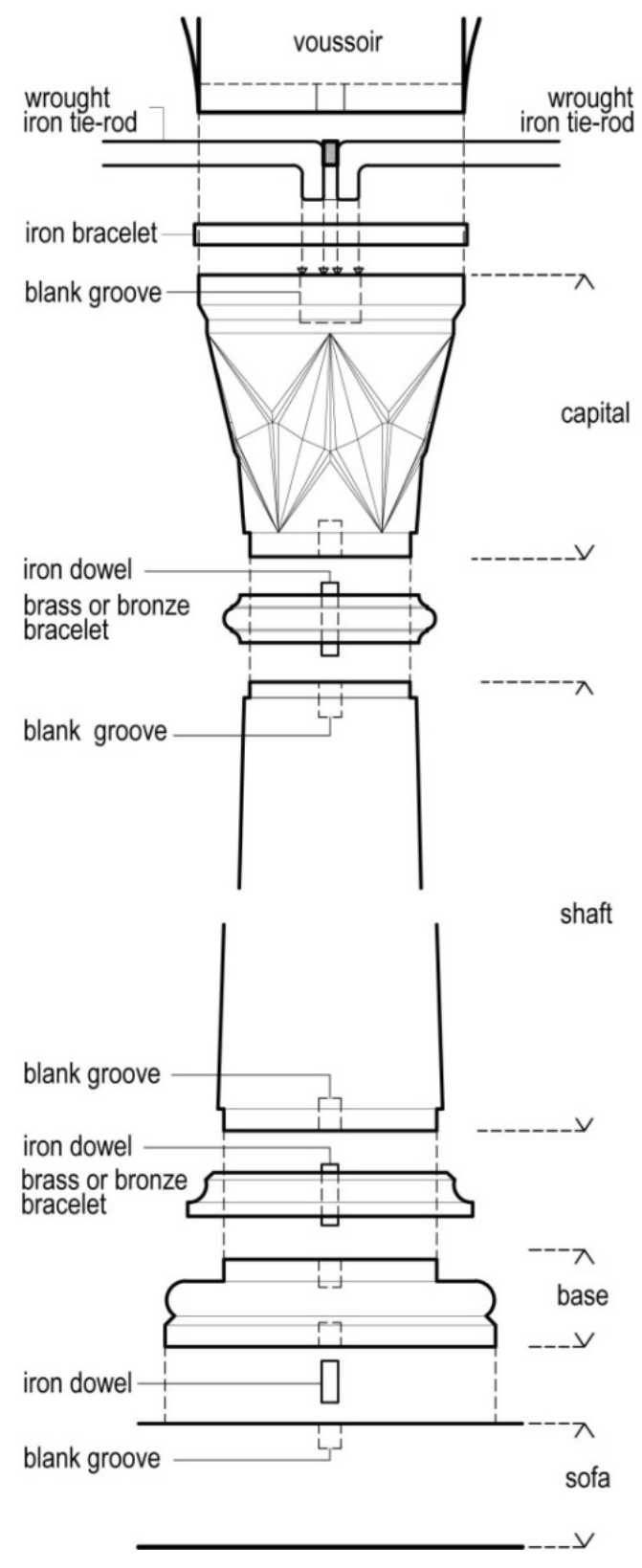

Figure 4. Schematic drawing of an ordinary column in Ottoman Classical Period (drawn by Author)

2 The pits that is at top and bottom of the capital, shaft and base.

Figure 4 shows the structural details of a column in the Ottoman Classical Period. The capitals are made of approximately a cubic marble block. At the top of the capital, there is a blank groove ${ }^{2}$ in which wrought iron tie-rods are connected from two or four directions at the same level (Ahunbay, 1988; Tanyeli, 1990; Tanyeli \& Tanyeli, 1993; Uluengin, 2006; Aksu \& Alaca, 2013). The wrought iron tie-rods were used to confront the thrust of arches and keep the structure as a whole. The blank groove in which the wrought iron tie-rods had been placed was filled with lead to prevent corrosion and fix the joint (Aksu \& Alaca, 2013). The capital on which an impost has been placed is connected to a 
cylindrical shaft. The columns were fixed to the sofa, and the capital with the iron pins and the molten lead filled the pin nests. This application has been known since antiquity (Ahunbay, 1988; Tanyeli \& Tanyeli, 1993; Uluengin, 2014; Alioğlu, 1991). The connection bracelet that is an unknown element in antiquity was used extensively in Ottoman architecture to close the connections between the capital, shaft, and base in addition to providing an aesthetic finish (Tanyeli \& Tanyeli, 1993; Sönmez, 1997). The material of the bracelets is brass or bronze. Moreover, a rectangular wrought iron tie-rod surrounding the upper limit of the capital increased the durability of the column against vertical loads (Figure 4).

\section{Structural Forms of Irregular Columns}

In this study, irregular columns were called CL1 and CL2 for each mosque (Table 1). Since all of the examined mosques are symmetrical relative to the north-south axis, each mosque presents two similar columns at this point. For this reason, in the following chapters, CL1 capital formations in different mosques are discussed, depending on their structures.

Table 1. Plan schemas of the mosques (plans: redrawn from Ayverdi, 1976, Ülgen, 1989; photographs source: Author, 2018)

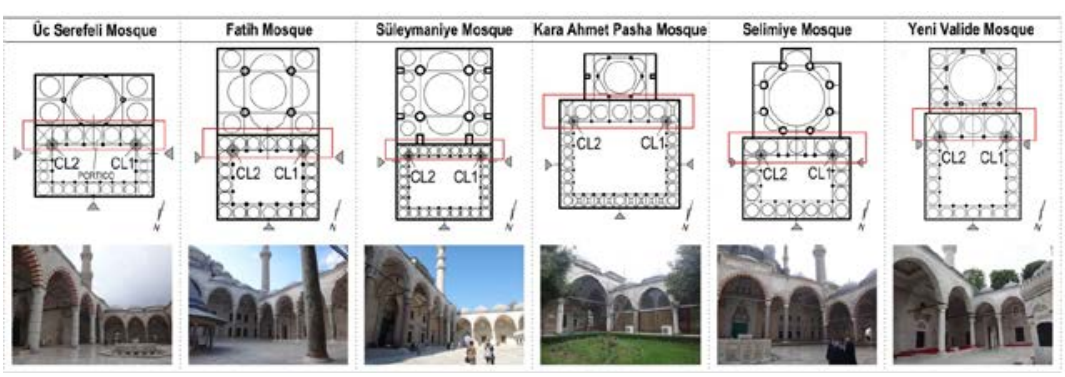

\section{Üç Şerefeli Mosque}

Üç Şerefeli Mosque was built in Edirne during the reign of Sultan Murad II between 1438 and 1447. The mosque consists of a prayer hall and a closed courtyard adjacent to this hall. The dimension of the prayer hall is $60.40 \mathrm{~m} \times 23.90 \mathrm{~m}$, and the closed courtyard $60.70 \mathrm{~m} \times 35.50 \mathrm{~m}$. A seven-bay space; the last prayer hall units at the corners are covered by cross vaults and remain units by domes (Table 1). The columns in the last prayer hall are $7.20 \mathrm{~m}$ in height with a diameter of $1.35 \mathrm{~m}$. Regarding the side porticos, height is $5.20 \mathrm{~m}$ and the diameter about $0.60 \mathrm{~m}$. 
Figure 5. The CL1 column, Üç Şerefeli Mosque: a) scaled drawings of current state (drawn by Author) b) photographs, 2018 (Source: Author)

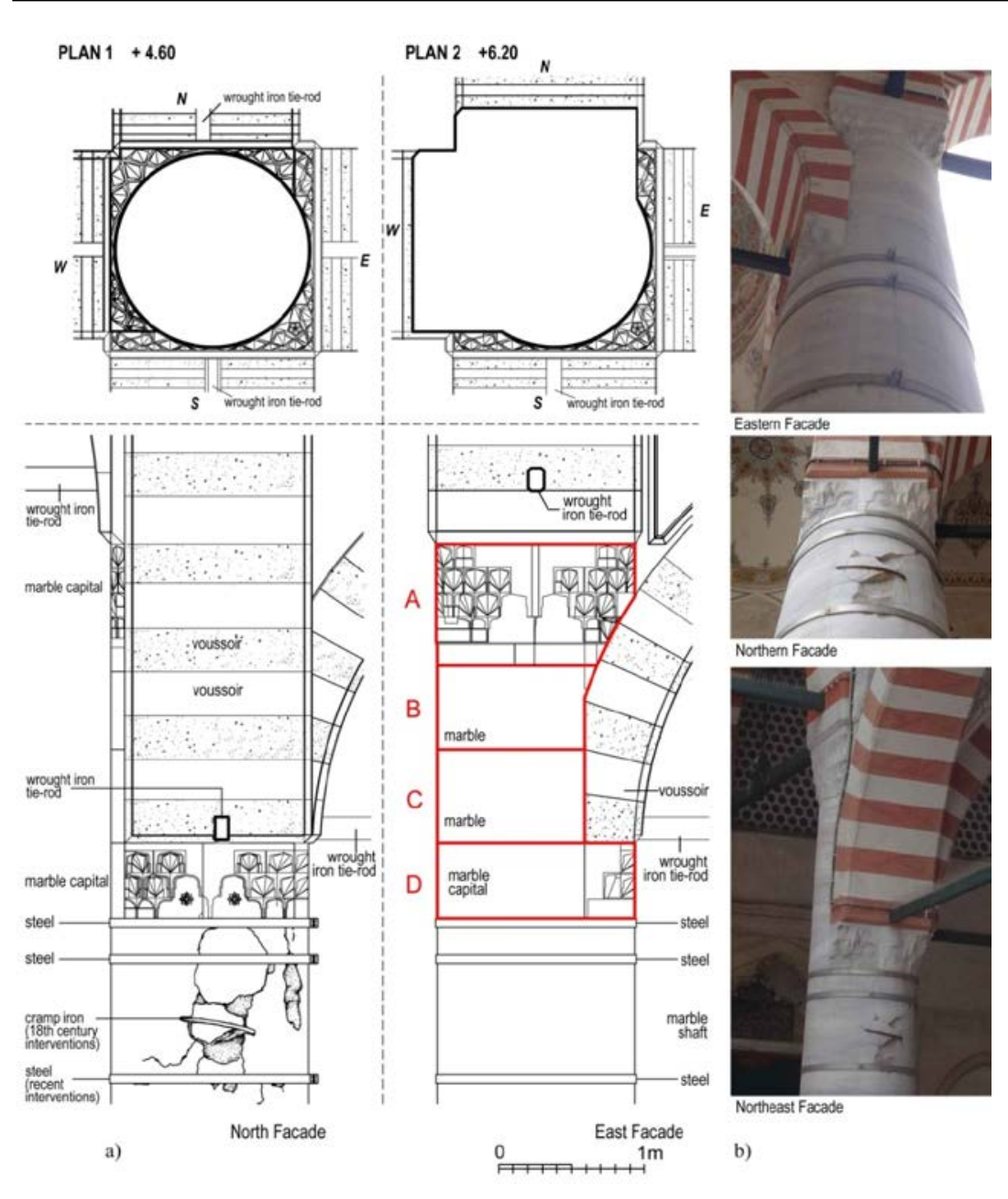

There are two capitals in CL1 and CL2; upper capital and lower capital. Between those, there is the transition part. This part can be defined as a part of vertical load bearing masonry section (a kind of pier). The capital is formed by placing four layers of blocks on top of each other. The upper and lower capitals consist of one block each (Blocks A and D in Figure 5a), and the transition part two blocks (Blocks $\mathrm{B}$ and $\mathrm{C}$ in Figure 5a). The blocks are not monolithic (Figure $5 \mathrm{a}, \mathrm{b}$ ). The arches are alternated with one row of red andesite and one row of beige limestone (Figure $5 a, b$ ). Because of the last prayer hall arches and the column diameter are equal; the muqarnas schema was applied only for the transition at the corners shown in Figure 5, Plan 1 (Table 3). The upper and lower capital forms a square on the plan layout, but their muqarnas schemas are different. In the connections between the capitals and the shaft, the bracelets have not been used (Figure 5a, b). The ratio of capital (the upper capital, the lower capital, and the transition part) to column height (from the sofa to top of the upper capital) is $\sim 1 / 2,8$. 


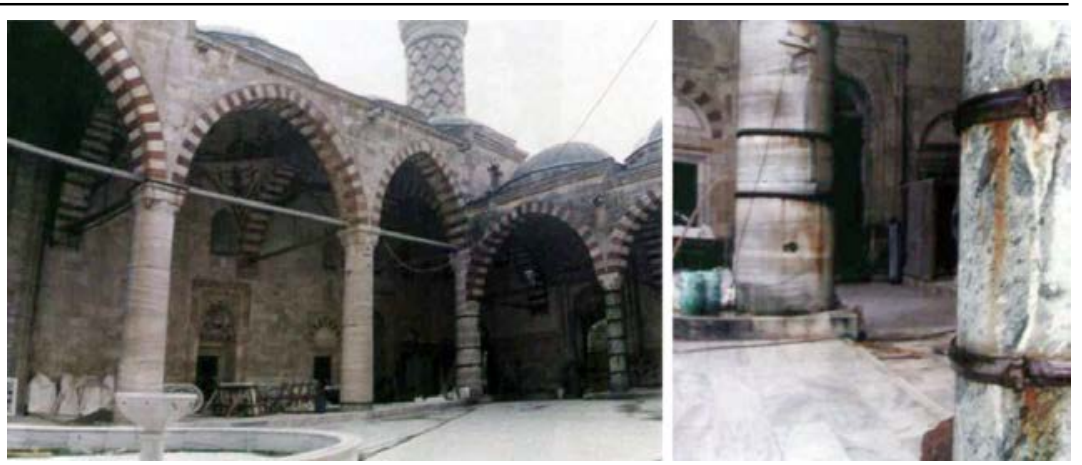

Figure 6. The CL1 column, Üç Şerefeli Mosque (Source: Altınsoy, 1999)

Regarding this monument that has undergone many repairs throughout history, the 18th-century repair is important. In this repair, the last prayer hall columns that were destroyed during the earthquake of 1752 were rebuilt using original pieces. The three iron bracelets and the cramp iron shown in Figure 6 were added to reinforce the CL1 in this process (Altınsoy, 1999). During the recent repair (between 1990 and 2006), iron bracelets were removed, and the shaft of the column was reinforced with six steel rings. The cramp iron added in the 18th-century repairs is still present (Figure 5a, b).

\section{Fatih Mosque}

Fatih Mosque was built in İstanbul by Atik Sinan between 1463 and 1470. The closed-courtyard has found its exact proportions and has become a classic example with this mosque (Cezar 1963; Aslanapa, 1986; Öz, 1987; Eyice, 1995). During the 1766 earthquake, the mosque was damaged severely and rebuilt with a different plan scheme. The closed-courtyard, the last prayer hall, and the prayer hall's northern wall remained from the original structure. The dimension of the prayer hall is approx. $45.00 \mathrm{~m} \mathrm{x}$ $48.00 \mathrm{~m}$ (exterior) in plan. The closed-courtyard is square in plan, $42.00 \mathrm{~m} \times 42.00 \mathrm{~m}$. The width of the portico surrounding the courtyard has an equal dimension in four directions and is covered by domes (Table 1 ). The columns at the last prayer hall are $8.75 \mathrm{~m}$ in height and approx. $0.90 \mathrm{~m}$ in diameter. While the columns at the side porticos are $5.45 \mathrm{~m}$ in height with a diameter of about $0.65 \mathrm{~m}$.

The capital was formed by placing four layers of monolithic blocks on top of each other. The upper and lower capitals consist of one block each (Blocks A and D in Figure 7a), and the transition part two blocks (Blocks B and $\mathrm{C}$ in Figure 7). The voussoirs are alternated in color; marble and red somaki (Figure $7 \mathrm{~b}$ ). The upper and lower capitals are similar in size and shape (Figure 7a, Plan1). The bracelets have not been used between the marble capitals and the granite main shaft as they were in the Üç Şerefeli Mosque (Figure 7a, b). The ratio of capital to the column height is $\sim 1 / 2,5$. 
Figure 7. The CL1 column, Fatih Mosque: a) scaled drawings of current state (drawn by Author) b) photographs, 2018 (Source: Author)
Figure 8. The CL1 column before restoration, Fatih Mosque, a) undated (Source: URL-1), b and c) a date between 1913 and 1963 (Source: Ali Saim Ülgen Archive, URL-1)
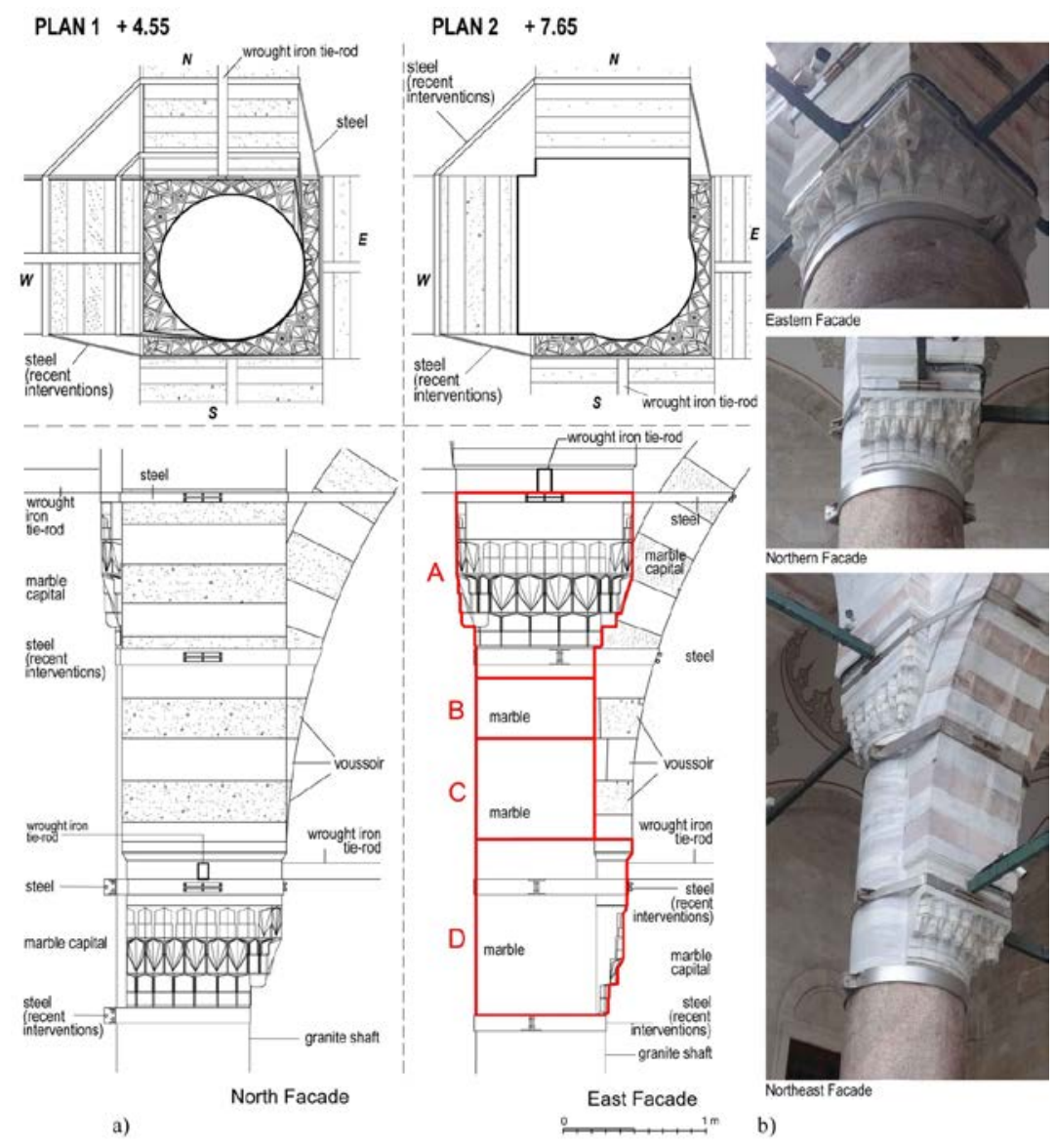

The building was recently repaired between 2007 and 2012 . During this restoration, the column surface was cleaned, iron strains were cleaned and painted, and cracks were repaired by injection. The wrought iron tie-rods that lost their function were removed and a new stainless steel system was installed to strengthen the structure (Ceylan and Ocakcan, 2013; Çll and Yıldız, 2013) (Figure 7a, b and 8).
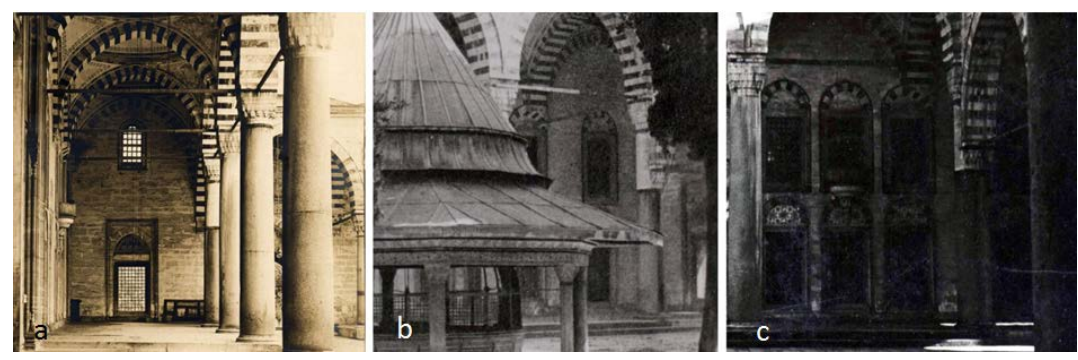

\section{Süleymaniye Mosque}

The Süleymaniye Mosque was built in Istanbul by Architect Sinan between 1551 and 1558. The dimension of the prayer hall is 64.00 $\mathrm{m} \times 68.00 \mathrm{~m}$, and the closed courtyard $47.00 \mathrm{~m} \times 61.00 \mathrm{~m}$. The widths of porticos are equal in four directions and covered by domes (Table 1). The columns bearing the nine-bay portico is 8.00 $\mathrm{m}$ in height with a diameter of $1.10 \mathrm{~m}$. Regarding the side porticos, height is $5.70 \mathrm{~m}$ and the diameter between $0.65 \mathrm{~m}$ and $0.70 \mathrm{~m}$. 
Characteristics of Irregular Column Capitals in Ottoman Mosques with Courtyards

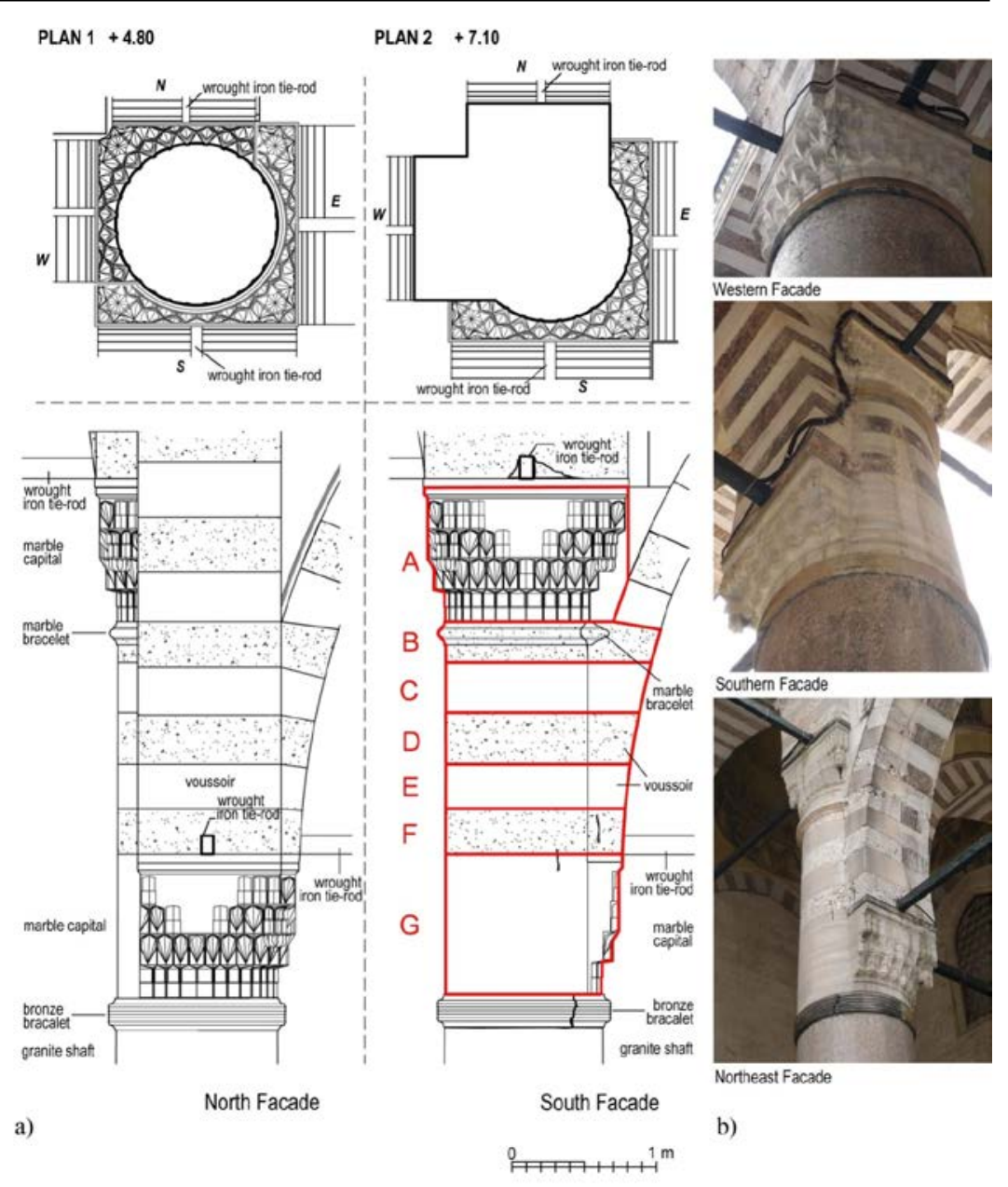

Figure 9. The CL1 column, Suleymaniye Mosque: a) scaled drawings of current state (drawn by Author) b) photographs, 2018 (Source: Author)

The capital was formed by placing seven layers of monolithic blocks on top of each other. The upper and lower capitals consist of one block each (Blocks A and G in Figure 9a), and the transition part five blocks (Blocks B-F in Figure 9a). The capitals form a square on the plan layout, and their muqarnas schemas are similar. There is only a slight difference appears in the Northwest corner of the lower capital (Figure 9a, Plan 1). The lower capital is connected to the granite main shaft with the bronze bracelet. However, the upper capital bracelet is carved out of puddingstone as a part of Block B (Figure 9a). The transition part blocks, which are alternated with one row of marble and one row of pudding, are carved together with the voussoirs (Figure 9). The ratio of capital to column height is $\sim 1 / 2,5$. The current appearance of the CL1 column is similar to the mid-20th century (Figure 10). 
Figure 10. The CL1 column, Süleymaniye Mosque; a) undated (source: URL-1), b and c) a date between 1913 and 1963 (Source: Ali Saim Ülgen Archive, URL-1)
Figure 11. The CL1 column, Kara Ahmet Pasha Mosque: a) scaled drawings of current state (drawn by Author) b) photographs, 2018 (Source: Author)
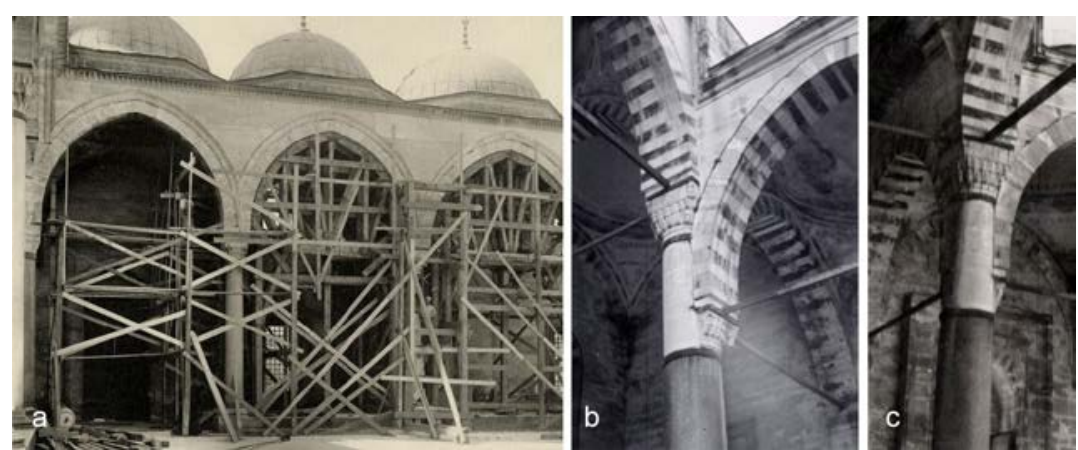

\section{Kara (Gazi) Ahmed Pasha Mosque}

The Kara Ahmed Pasha Mosque was built in Topkapı, İstanbul by Architect Sinan between 1565 and 1567. The dimension of the prayer hall is $18.50 \mathrm{~m} \times 26.60 \mathrm{~m}$, and the closed courtyard 46.93 $\mathrm{m} \times 37.43 \mathrm{~m}$. The width of the seven-bay last prayer hall is about twice of the side porticoes. As a result of this, the corner units in the last prayer hall are rectangular and are covered by cross vaults, remaining units by domes (Table 1). The columns in the last prayer hall are $4.00 \mathrm{~m}$ in height with a diameter of $0.53 \mathrm{~m}$. Regarding the side porticos, height is $2.78 \mathrm{~m}$ and the diameter about $0.54 \mathrm{~m}$.

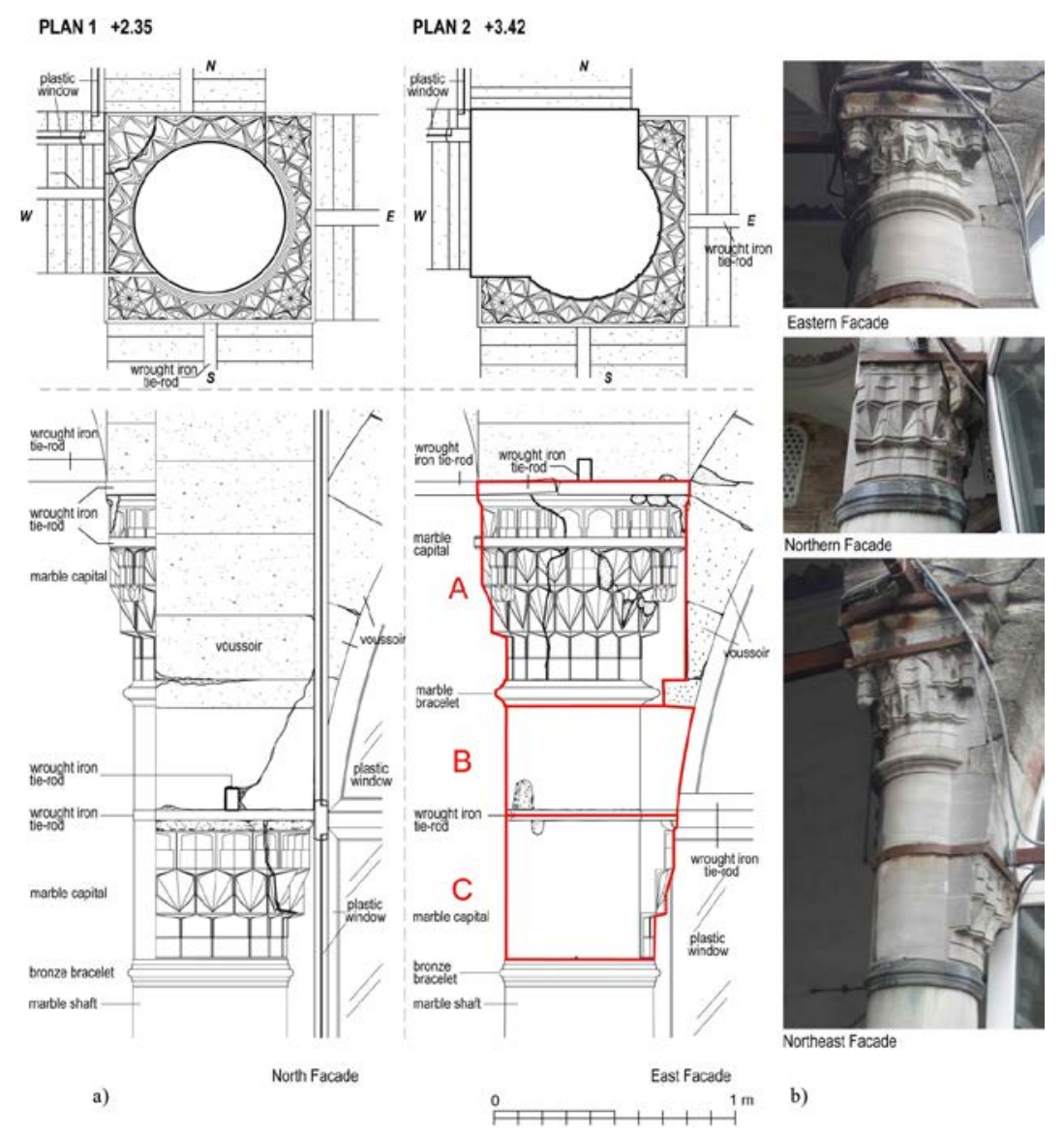


Characteristics of Irregular Column Capitals in Ottoman Mosques with Courtyards

The capital was formed by placing three layers of monolithic marble blocks on top of each other. The upper and lower capitals, with the transition part, are made of one block each (Blocks A, B, $\mathrm{C}$ in Figure 11a). The upper and lower capital forms a square on the plan layout, but their muqarnas schemas are different (Figure 11a, Plan 1). The lower capital is connected to the marble main shaft with the bronze bracelet. However, the upper capital bracelet is carved out of marble as a part of Block A (Figure 11a). The transition part is carved together with the impost (Figure 11). The ratio of capital to column height is $\sim 1 / 3$.
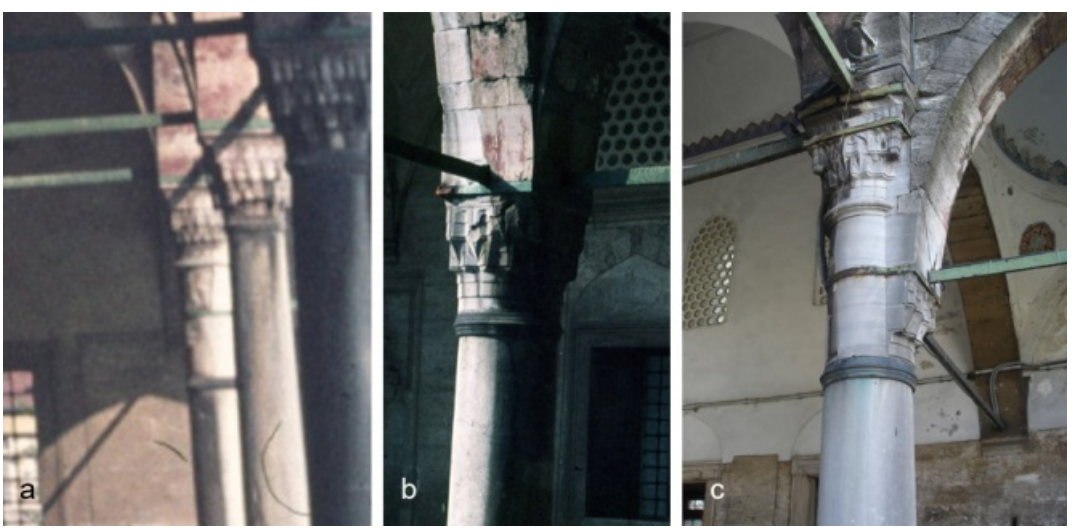

The columns are ruined today. The upper two muqarnas rows of the lower capital are detached (Northern view in Figure 11b). For this reason, an iron bracelet, which is available today, was added between the 3rd and 4th rows of the capital in previous repairs (Figure 11 and 12).

\section{Selimiye Mosque}

The Selimiye Mosque was built in Edirne by Architect Sinan between 1568 and 1574 . The prayer hall and the closed courtyard are about the same size, $44.00 \mathrm{~m} \times 60.00 \mathrm{~m}$. The porticos' widths are equal in all four sides. A seven-bay space; last prayer hall units are covered by cavetto vaults and domes (Table 1). The columns in the last prayer hall are $8.30 \mathrm{~m}$ in height with a diameter of 0.84 $\mathrm{m}$. Regarding the side porticos, height is $5.20 \mathrm{~m}$ and the diameter about $0.75 \mathrm{~m}$.

The capital was formed by placing four layers of the monolithic marble blocks on top of each other (Figure 13b). The upper and lower capitals consist of one block each (Blocks A and D in Figure 13a), and the transition part two blocks (Blocks B and C in Figure 13a). The arches are alternated with one row of red andesite and one row of beige limestone, similar to Üç Şerefeli Mosque. The size and shape of the capitals are affected by the arches which have different widths in three directions (Figure 13a, Plan1). The schema of the rectangular upper capital has symmetrical on the
Figure 12. The CL1 column, Kara Ahmed Pasha Mosque: a, b) 1986 (Source: Kemali Söylemezoğlu Archive, URL-1), c) 2011 (Source: Author) 
courtyard-face, while not symmetrical on the portico-face (Figure 13a, plan 2 and 9b, Southern facade). The capitals connect to the main shaft and the transition part with the bronze bracelets (Figure 13b). The ratio of capital to column height is $\sim 1 / 2$. The current appearance of the CL1 column is similar to the mid-20th century (Figure 14).

Figure 13. The CL1 column, Selimiye Mosque: a) scaled drawings of current state (drawn by Author) b) photographs, 2018 (Source: Author)

Figure 14. The CL1 column, Selimiye Mosque: a-c) a date between 1913 and 1963 (Source: Ali Saim Ülgen Archive, URL-1)

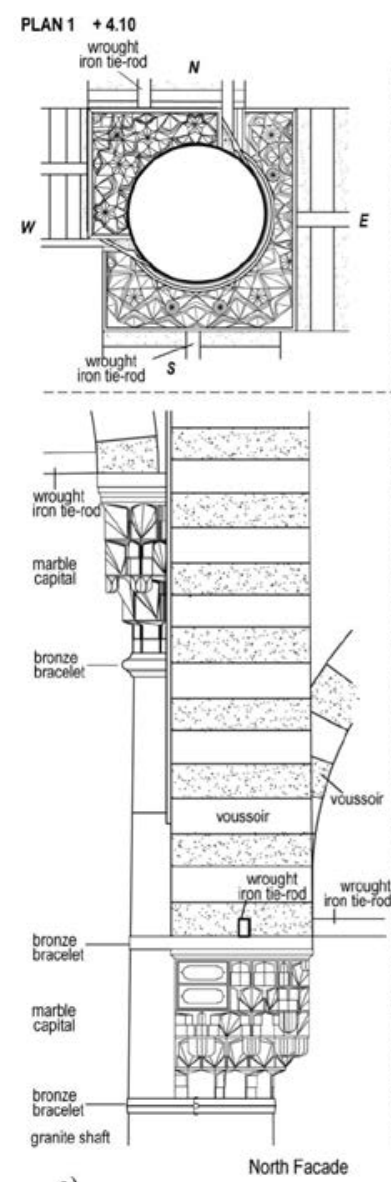

a)
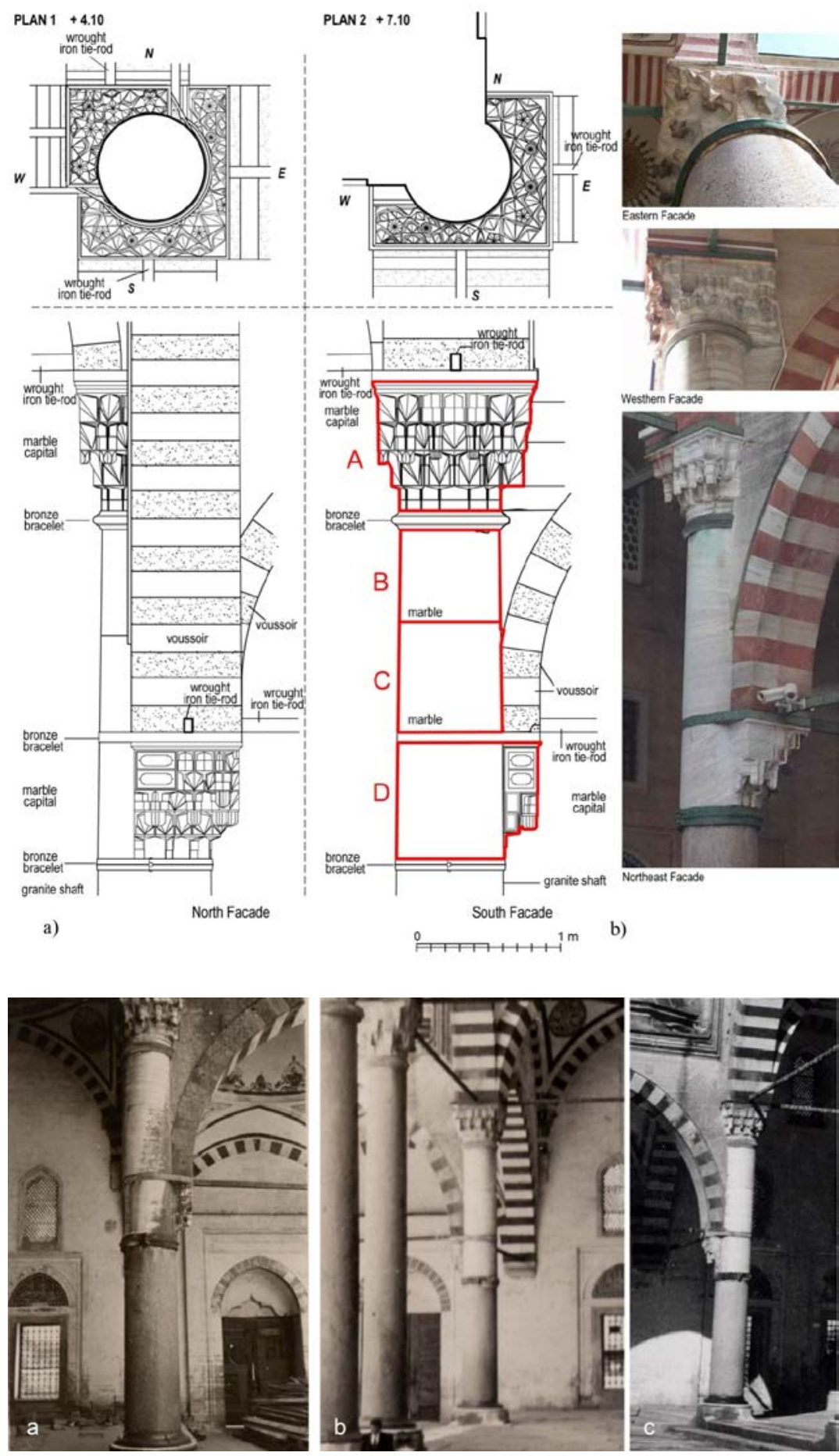
Characteristics of Irregular Column Capitals in Ottoman Mosques with Courtyards

\section{Valide-i Cedid Mosque}

The Yeni Valide Mosque was built in İstanbul between 1708 and 1710 about 300 years after the first practice. The dimension of the prayer hall is $21.00 \mathrm{~m} \times 27.00 \mathrm{~m}$, and the closed courtyard 31.00 $\mathrm{m} \times 30.00 \mathrm{~m}$. The width of the five-bay last prayer hall is about twice the side porticoes (Table 1). Accordingly, rectangular units in the corners are covered by vaults, remaining units by domes. The columns in the last prayer hall are $5.25 \mathrm{~m}$ in height with a diameter of $0.70 \mathrm{~m}$. Regarding the side porticos, height is $4.50 \mathrm{~m}$ with a diameter of $0.60 \mathrm{~m}$.

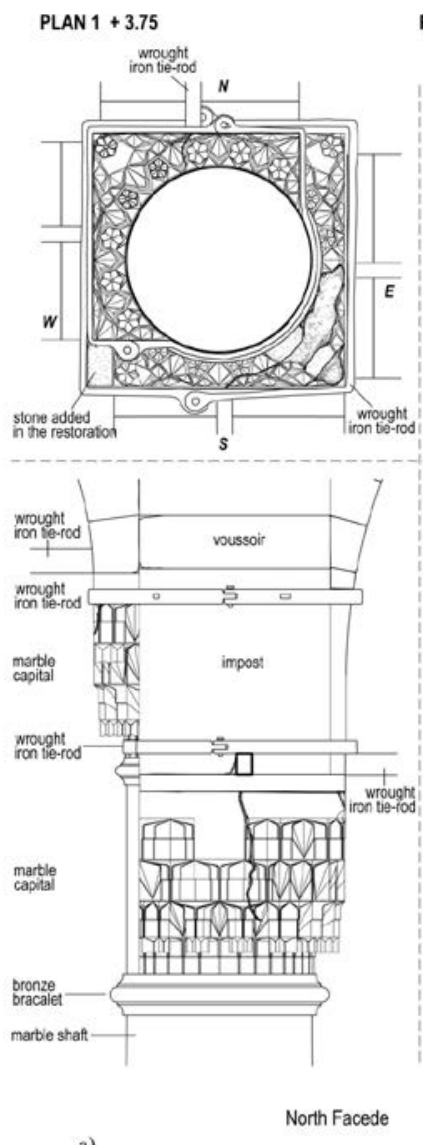

PLAN $2+4.55$
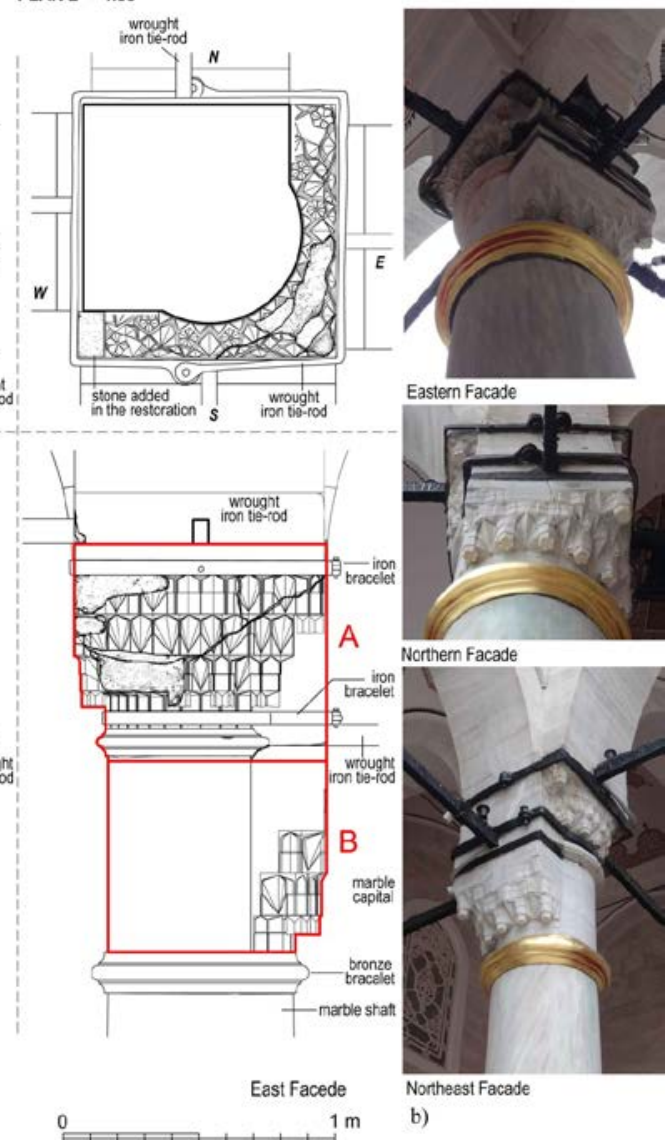

The capital was formed by placing two layers of monolithic blocks on top of each other. The upper and lower capitals consist of one block each (Blocks A and B in Figure 15a). There is no transition part between them. The capitals and the voussoirs are marble (Figure 15b). The schemes of the upper and lower capitals are similar except for minor differences (Plan 1 in Figure 15a). The lower capital is connected to the marble main shaft with the bronze bracelet, while the upper capital bracelet is formed with block A and made of marble (Figure 15). The ratio of capital to column height is $\sim 1 / 4$.
Figure 15. CL1 column, Valide-i Cedid Mosque: a) scaled drawings of current state (drawn by Author) b) photographs, 2018 (Source: Author) 
Figure 16. The CL1 column, Yeni Valide Mosque: a) late 19th century - early 20th century (Source: URL2), b) before recent restoration, 2013 (Source: Author)
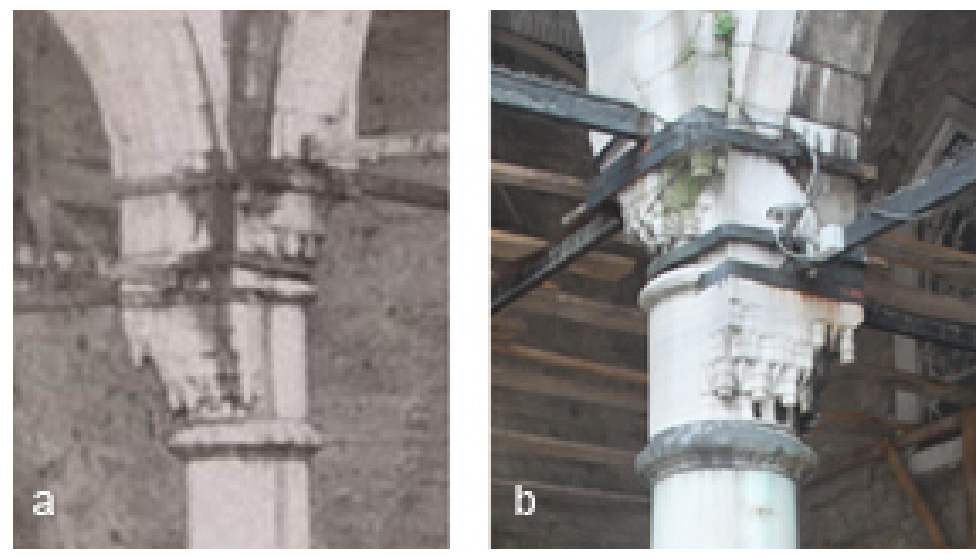

There are two iron bracelets on the upper capital. Figure 16 shows that these bracelets in the CL1 existed in the late 19th century early 20th century. They have been added in a repair before this date. The last repair of the mosque was made between 2013 and 2015. During this restoration, the surface was cleaned, iron tie rods were cleaned and painted, and cracks were repaired by injection (Figure 15).

\section{EVALUATION AND CONCLUSION}

According to the data obtained from this study, the features of the capitals vary depending on several factors:

- Construction period: The capitals were made in a period for about 300 years. There are dimensional and formal differences between the capitals of early and late period mosques. For example, the shafts of the last prayer hall are thicker than the side porticos in all samples. This dimensional difference is about twice as much in the early period mosques and gradually decreased toward the late period (Table 2, 3). Also in the early period examples (Üç Şerefeli Mosque and Fatih Mosque) there are no bracelets in the connections of the shaft, capital and transition part however there are in the late period mosques (Table 3). The blocks forming the capitals are monolithic except Üç Şerefeli Mosque.

- The relationship between the last prayer hall and courtyard: The porticos' dimensions are the primary factor in the capitals' differences. Different portico widths and heights affect the capitals' heights, and thus, affect the shape of the lower and upper capitals (Table 3). It is not possible to select a ratio that would cover all the columns. The ratio of the column capital to column height is in the range of $1 / 2-1 / 3$ in five of the columns. Only in Valide-i Cedid Mosque, this ratio is $1 / 4$ because there is no shaft between the lower and upper capitals (Table 2, 3). 
Characteristics of Irregular Column Capitals in Ottoman Mosques with Courtyards

Table 2. The CL1 column dimensions (Source: Author)

\begin{tabular}{|c|c|c|c|c|c|c|c|}
\hline \multirow{2}{*}{ MOSQUES } & \multicolumn{2}{|c|}{ column height (m) } & \multicolumn{2}{|c|}{$\begin{array}{l}\text { column diametre } \\
(\mathrm{m})\end{array}$} & \multicolumn{2}{|c|}{ arch width (m) } & \multirow{2}{*}{$\begin{array}{c}\text { ratio } \\
\text { capital/column } \\
\text { height }\end{array}$} \\
\hline & CL1 & $\begin{array}{c}\text { side } \\
\text { porticos }\end{array}$ & CL1 & $\begin{array}{c}\text { side } \\
\text { porticos }\end{array}$ & CL1 & $\begin{array}{c}\text { side } \\
\text { porticos }\end{array}$ & \\
\hline $\begin{array}{l}\text { Üç Șerefeli } \\
\text { Mosque }\end{array}$ & 7.20 & 5.20 & 1.35 & 0.60 & 1.35 & 1.00 & $1 / 2.8$ \\
\hline Fatih Mosque & 8.75 & 5.45 & 0.90 & 0.65 & 1.13 & 0.98 & $1 / 2.5$ \\
\hline $\begin{array}{l}\text { Süleymaniye } \\
\text { Mosque }\end{array}$ & 8.00 & 5.70 & 1.10 & 0.65 & 1.35 & 0.97 & $1 / 2.5$ \\
\hline $\begin{array}{l}\text { Kara Ahmed } \\
\text { Pasha Mosque }\end{array}$ & 4.00 & 2.78 & 0.53 & 0.45 & 0.72 & 0.54 & $1 / 3$ \\
\hline $\begin{array}{l}\text { Selimiye } \\
\text { Mosque }\end{array}$ & 8.30 & 5.20 & 0.84 & 0.75 & 1.35 & 0.80 & $1 / 2$ \\
\hline $\begin{array}{l}\text { Yeni Valide } \\
\text { Mosque }\end{array}$ & 5.25 & 4.50 & 0.70 & 0.60 & 0.84 & 0.72 & $1 / 4$ \\
\hline
\end{tabular}

Table 3. The CL1 column capitals of the mosques (Source: Author)

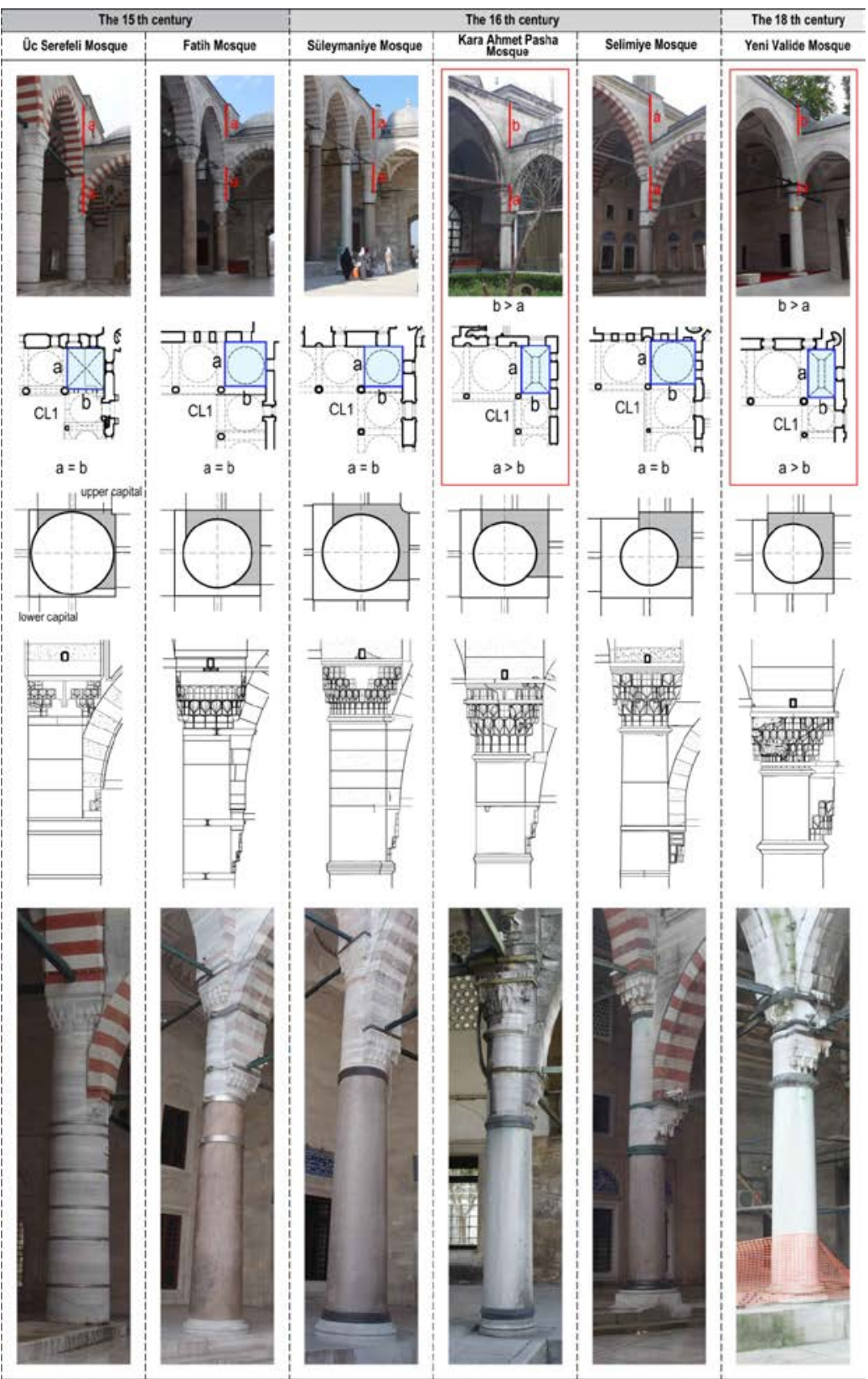


- Structural aspects: The structural necessities have been taken precedence over to the visual concern. For example, in the Selimiye Mosque, the shape of the capital and accordingly its muqarnas schema of upper capital differ due to the different arch widths (Western facade in Figure 13b, Table 3).

- Visual concern: The height of the capitals is linked to the height of the last prayer hall but is not always directly proportional. For example, in the Kara Ahmet Pasha and the Yeni Valide Mosques, the height difference between their porticos is more than their capitals' height; however, it is equal in the other mosques (Table 3). Another reason for the differences in the capitals is the diversity of the schema that increases the visual richness. Having the capitals in one of the most intense regions of visual perception has created an appropriate environment in which the master-builder could have demonstrated all of his skills (Table 3).

Figure 17. Construction details of the CL1 column capital, Kara Ahmet Pasha Mosque (Drawn by Author)

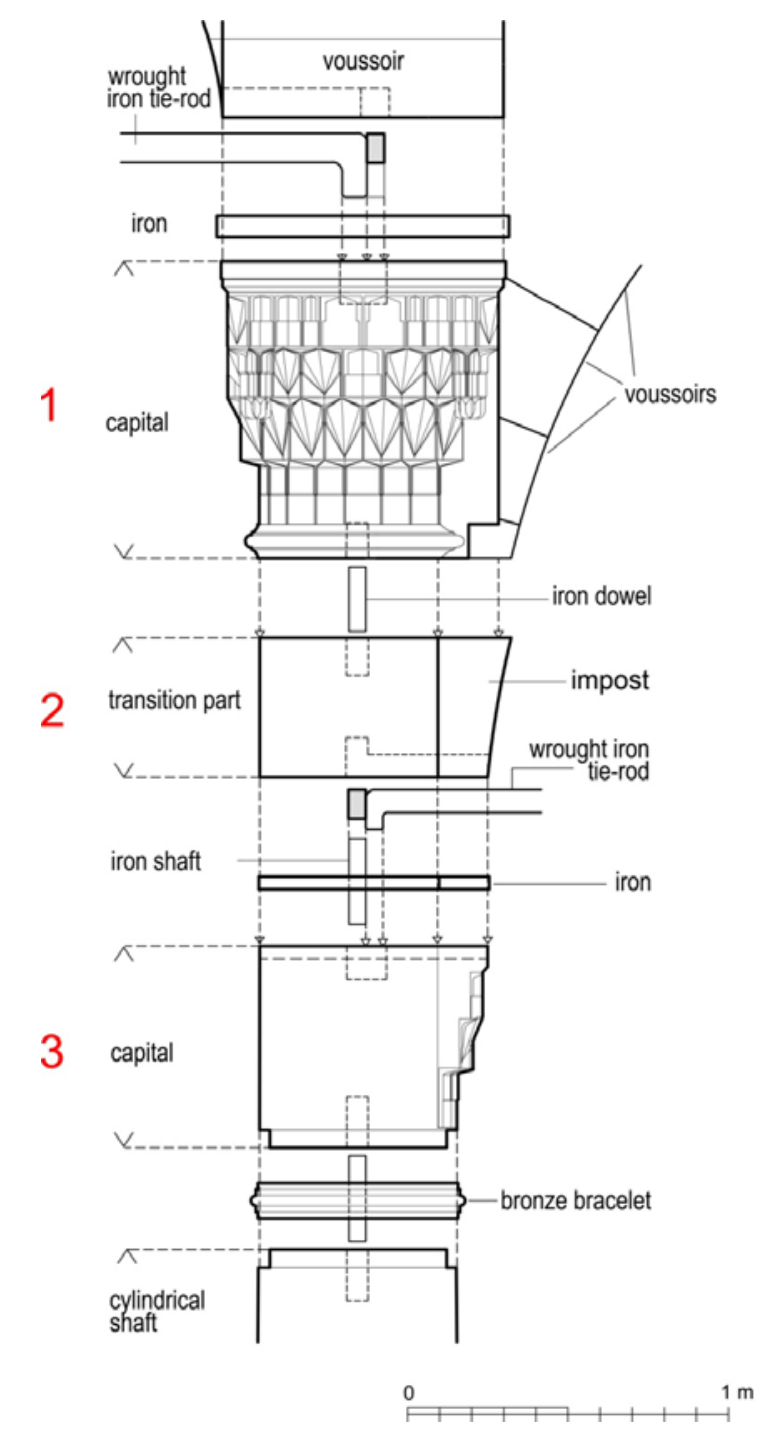


Although the size and shape of these six column capitals differ, their construction techniques are similar. The capital consists of three parts: upper capital, lower capital, and transition part as shown in Figure 17 and 18. The vertical iron shaft should have been used in the connection of the blocks as in an ordinary column. The portico arches are connected to the upper capital. For this reason, the capital's shape, size, and material are similar to the portico capitals. The arches of the side porticos were connected to the lower capital, so its characteristics appear to be similar to the capitals at the side porticos. The stone bracelet carved out together with the upper capital (Figure 18, Block 1). At the top of the capitals, a groove that was used for connecting wrought iron tie-rods similar to a typical capital can be seen. However, since only the portico's two arches were attached to the upper capital, two wrought iron tie-rods were connected at this level. On top of this, the imposts of the last prayer hall's arches were placed. In Block 2, the imposts of the side portico's arches were carved together with the transition part. The lower capital (Figure 18, Block 3) connected to the cylindrical shaft with a bronze bracelet (Figures 17, 18).

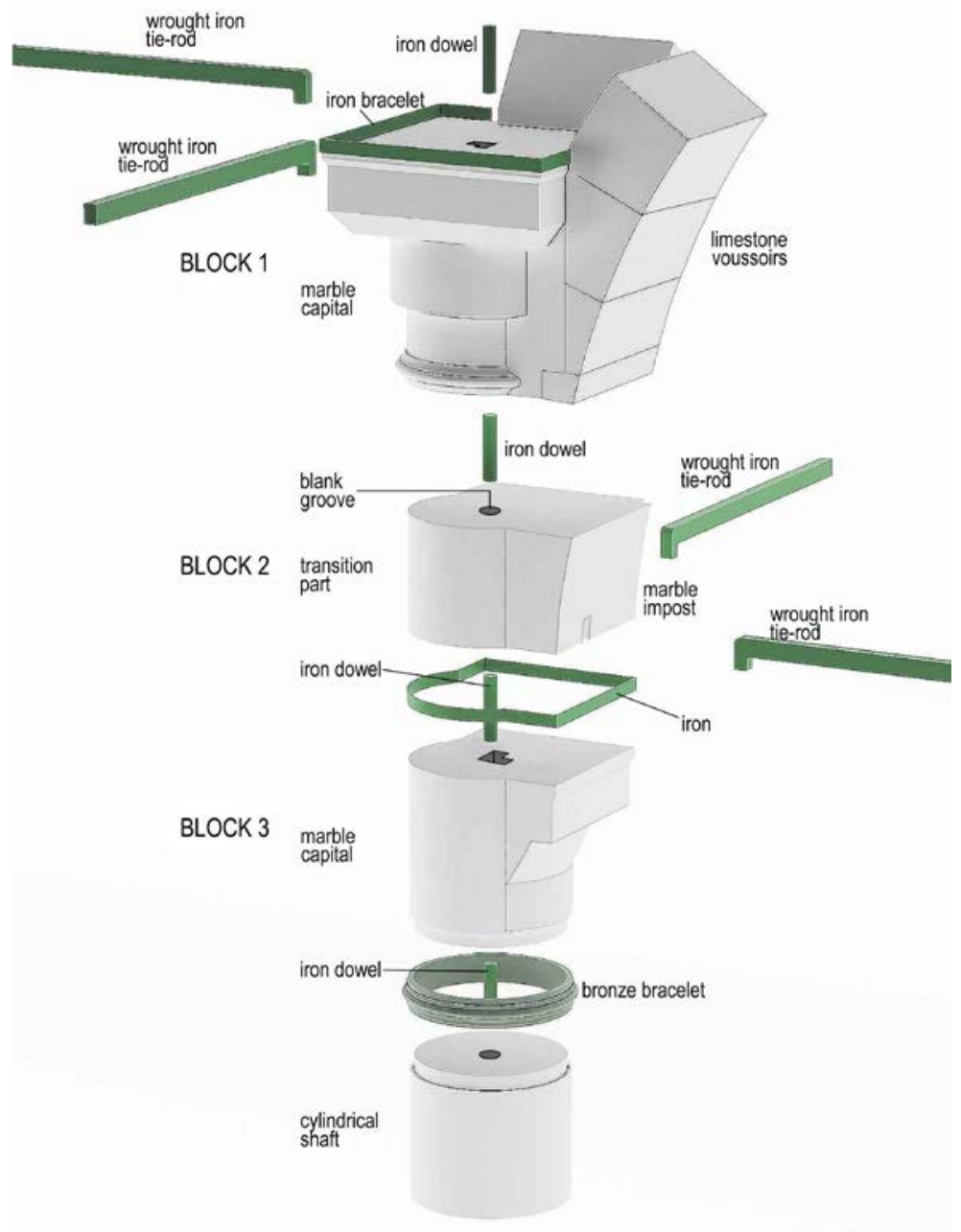

Figure 18. 3D representation (model) of CL1 column capital (Drawn by Author) 
Two separate structures that were connected at different heights caused formal differentiation of the columns, and this formation becomes one of the unique examples in Ottoman architecture. We can define these examples as a different interpretation of a traditional practice that emerged as a result of structural necessities. In this point, documenting the present conditions of the capitals, which survived to the present day by preserving their original appearance on a large scale despite minor reinforcement additions, will also provide an important resource for conveying this tradition to future generations.

\section{REFERENCES}

Ahunbay, Z. (1988). Sinan'ın yapılarında kullanılan teknikler ve malzeme. Mimarbaşı Koca Sinan, Yaşadığı Çağ ve Eserleri (ss. 531-538). S. Bayram (Ed). İstanbul: Vakıflar Genel Müdürlüğü.

Ahunbay, Z. (2012). Selimiye Mosque and its social complex. Ankara: Ministry of Culture and Tourism.

Aksu, H. D. and Alaca, Ç. (2013). Üsküdar Atik Valide Külliyesi restorasyon uygulamalarından örnekler. Kagir Yapılarda Koruma ve Onarım Semineri V (03-04 Aralık 2013), 57-71.

Alioğlu, F. (1991). Geleneksel yapı elemanları. (Yayımlanmamış ders notu). Yıldız Teknik Üniversitesi, İstanbul.

Alper, B. (1998). İstanbul'daki Mimar Sinan camileri'nde sütunlar, biçim, malzeme ve boyut özellikleri. (Yayımlanmamış doçentlik çalışması) Yıldız Teknik Üniversitesi, İstanbul.

Altınsoy, M. G. (1999). Edirne camilerinde 18. yüzyıl onarımları. (Yayınlanmamış doktora tezi). İstanbul Teknik Üniversitesi. Fen Bilimleri Enstitüsü. İstanbul.

Aslanapa, 0. (1986). Osmanl devri mimarisi: Orhan Gaziden bașlayarak sonuna kadar padișahlara göre gelișmesi. İstanbul: İnkılap Kitapevi.

Ayverdi, E. H. (1989). Osmanli mimarisinde Fatih Devri 855-886 (1451-1481). İstanbul: Fetih Cemiyeti İstanbul Enstitüsü Yayınları.

Ayverdi, E. H. and Yüksel İ. A. (1976). İlk 250 senenin Osmanlı mimarisi. İstanbul: Fetih Cemiyeti İstanbul Enstitüsü Yayınları.

Barkan, Ö. L. (1979). Süleymaniye Camii ve İmareti inşaatı (2. cilt). Ankara: Türk Tarih Kurumu Yayınları.

Cantay, G. (2013). Fatih Camii ve Sultan I. Mahmut Kütüphanesi onarımında bezeme çalışmaları. Vakıf Restorasyon Yıllı̆̆ı, 7, 96-108.

Çelik, S. (2009). Süleymaniye Külliyesi malzeme, teknik ve süreç. Ankara: Atatürk Kültür Merkezi Yayınları.

Ceylan, O. (2013). Rekonstrüsiyon yeniden yapım yöntemi üzerine bir değerlendirme. Kagir Yapılarda Koruma ve Onarım Semineri V (03-04 Aralık 2013), 132-154.

Ceylan, O. and Ocakcan, T. K. (2013). Fatih Camii 2007-2012 restorasyonu uygulamaları. Vakıf Restorasyon Yıllığı, 7, 44-63. 
Cezar, M. (1963). Osmanlı devrinde İstanbul yapılarında tahribat yapan yangınlar ve tabii afetler. Türk Sanatı Tarihi Araştırma ve Íncelemeleri Dergisi, 1, 327-349.

Çıll, F. and Yıldız, H. (2013). Fatih Camii ve I. Mahmut Kütüphanesi güçlendirme çalışmaları. Vakıf Restorasyon Yıllı̆̆ı, 7, 6584.

Çuhadar, Ö. (2011). Bursa camilerinde revak, erken dönem üzerine bir deneme. Bursa: Bursa Kültür A.Ş. Yayınları.

Erdoğan, M. (1962). Son incelemelere göre Fatih Camii'nin yeniden inşası meselesi. Vakıflar Dergisi, 5, 161-192.

Eyice, S. (1995). Fatih Camii ve Külliyesi. TDV İslam Ansiklopedisi, 12, 244-249, İstanbul: Türkiye Diyanet Vakfı Yayın Matbaacillk.

Goodwin, G. (2003). A history of Ottoman architecture. London: Thames \& Hudson.

Kolay, İ. and Çelik, S. (2007). Malzeme ve teknoloji. In S. Mülayim (Ed.), Bir şaheser Süleymaniye Külliyesi, Ankara: TC Kültür ve Turizm Bakanlığı Yayınları, 125-147.

Köroğlu Orbeyi, N. (2012). Mimar Sinan camileri revak sütunları üzerine bir araştırma: Süleymaniye Camisi, Selimiye Camisi ve Kara Ahmet Paşa Camisi örnekleri. Erciyes Üniversitesi Fen Bilimleri Enstitüsü Fen Bilimleri Dergisi, 28 (3), ss. 175-185.

Kuran, A. (1964). Illk devir Osmanlı mimarisinde cami. Ankara: ODTÜ Mimarlık Fakültesi Yayınları.

Macaulay, D. (2010). Cami. İstanbul: Kaknüs Yayınları.

Mülayim, S. (2008). Revak. TDV İslam Ansiklopedisi. İstanbul: Türkiye Diyanet Vakfı Yayın Matbaacılık, 35, 22-24.

Mülayim, S. (2010). Sütun. TDV İslam Ansiklopedisi. İstanbul: Türkiye Diyanet Vakfi Yayın Matbaacılık, 38, 181-182.

Orbeyi, N. (2016). Çift revaklı Sinan camilerinde modüler sistem. Metu Journal of The Faculty of Architecture, 33, 2 , 201-225. doi: 10.4305/METU.JFA.2016.2.7

Öz, T. (1987). İstanbul camileri, I, Ankara: TTK Yayınları.

Özüdoğru, Ş. (2005). Erken ve Klasik Devir Osmanlı camilerinde son cemaat yerlerinin gelişimi ve tipolojisi. Eskişehir: TC Anadolu Üniversitesi Yayınları.

Sönmez, N. (1997). Osmanlı Dönemi yapı ve malzeme terimleri sözlüğü. İstanbul: YEM Yayınları.

Sönmezer, Ş. (2002). İstanbul'daki Sinan camilerinde mekan ile serbest düşey taşıyıcılar arasındaki boyut ilişkisi (Yayımlanmamıș Doktora Tezi). İstanbul Teknik Üniversitesi Fen Bilimleri Enstitüsü, İstanbul.

Tanyeli G. (1990). Osmanlı mimarlığında demirin strüktürel kullanımı (15-18.yy) (Yayımlanmamış Doktora Tezi). İstanbul Teknik Üniversitesi Fen Bilimleri Enstitüsü, İstanbul.

Tanyeli, G. and Tanyeli, U. (1993). 16. yüzyıl Osmanlı mimarlık teknolojisi. In M. Saçlığlu, G. Tanyeli (Ed.), Türk kültüründe sanat ve mimari: Klasik Dönem sanatı ve mimarlı̆̆ı üzerine denemeler. İstanbul: 21. Yüzyll Eğitim ve Kültür Vakfl, 125-156.

Tayla, H. (2007). Geleneksel Türk mimarisinde yapı sistem ve elemanları. I, İstanbul: TAÇ Vakfi Yayınları. 
Ülgen, A. S. (1989). Mimar Sinan yapıları (Katalog). Ankara: TTK Yayınları.

Uluengin, B. (2006). Mimari metaller, özellikleri, bozulma nedenleri, koruma ve restorasyon teknikleri. İstanbul: Birsen Yayınevi.

Uluengin, F., Uluengin, B., and Uluengin, B. (2014). Osmanlı anit mimarisinde klasik yapı detayları. İstanbul: Yapı Endüstri Merkezi Yayınları.

Yetkin, S. K. (1955). Beylikler Devri mimarisinin Klasik Osmanlı sanatını hazırlayışı. Ankara Üniversitesi İlahiyat Fakültesi Dergisi, 3-4, 39-43.

Yorulmaz, M., Ahunbay, Z. (1986). Sinan camilerinde taşıyıcı sistem ve yapım teknikleri. II. Uluslararası Türk ve İslam Bilim Teknoloji Tarihi Kongresi, 3, 123-144.

URL-1 http://saltonline.org

URL-2 http://www.eskiistanbul.net/2033/yeni-valide-camiisadirvani-nikolai-andreomenos-fotografi

\section{Resume}

She received his B.Arch and MSc. in Architecture Department, from Yıldız Technical University, Faculty of Architecture (1997-2004). She earned her PhD. degree in in Building Survey and Restoration Programme from Yildiz Technical University (2010). She is currently working as an Assistant Professor at Mimar Sinan Fine Arts University. 